\title{
Seismic Source Modeling in the Shores of Western Makran
}

\author{
Mahdi Modiri1 ${ }^{*}$, Amir Barzegari², Amir Sahebalzamani ${ }^{3}$, AbdolReza Hashemi4 \\ ${ }^{1}$ Malek-Ashtar University of Technology, Shiraz, Iran \\ ${ }^{2}$ North Tehran Branch of Azad University, Tehran, Iran \\ ${ }^{3}$ Iran University of Science and Technology, Tehran, Iran \\ ${ }^{4}$ Tarbiat Moallem University, Tehran, Iran \\ Email: ‘barzegariamir@yahoo.com, Sahebzamani1989@gmail.com, mmodiri@ut.ac.ir, Arhashemi.2005@gmail.com
}

How to cite this paper: Modiri, M., Barzegari, A., Sahebalzamani, A. and Hashemi, A. (2017) Seismic Source Modeling in the Shores of Western Makran. Open Access Library Journal, 4: e4094.

https://doi.org/10.4236/oalib.1104094

Received: October 30, 2017

Accepted: November 27, 2017

Published: November 30, 2017

Copyright @ 2017 by authors and Open Access Library Inc.

This work is licensed under the Creative Commons Attribution International License (CC BY 4.0).

http://creativecommons.org/licenses/by/4.0/

cC) (i) Open Access

\begin{abstract}
Makran is an active subduction zone with a lower activity rate in comparison with other similar subduction zones. In the extent of Makran seismotectonic province, from coastline up to $70 \mathrm{Km}$ distance onshore, the earthquakes are shallow whilst further inland, focal depths of the earthquakes are deeper. Considering the low seismic activity rate, lack of adequate and reliable seismic data and uncertainty about earthquake hazard contribution ratio of subduction segments and faults, it is intended in this article to determine the most accurate method of seismic source modelling. Estimation of the maximum strong ground motion in this province has been assessed by assuming various combinations of activity rate contribution ratios, i.e. independent activity of either subduction source or faults or simultaneous activity of subduction source and faults. According to the obtained results, the maximum and minimum limits of the strong ground motion acceleration is related to the independent seismic activity models and when subduction source and faults are assumed to be contributing simultaneously to the activity rate of the region, the resultant ground motion acceleration will be between the limits obtained based on independent activity models.
\end{abstract}

\section{Subject Areas}

Geophysics

\section{Keywords}

Hazard Analysis, Makran Coast, Maximum Acceleration of Strong Ground Motion, Subduction Zone, Sistan and Balouchestan 


\section{Introduction}

According to historic and prehistoric evidences, Iran has been struck by many massive earthquakes owing to its location (Alp-Himalaya mountainous belt) and as a result of these earthquakes, many civilizations with thousands of years historical backgrounds were eradicated including Komes civilization located in modern day Seimare which was destroyed under heavy impact of the 7.6 surface wave magnitude earthquake at December $22^{\text {th }} 856 \mathrm{AD}$ [1]. In recent years, massive earthquakes with surface waves magnitude greater than 6 happened in some parts of Iran including Bam and Zarand in Kerman province, Varzaghan in east Azerbaijan province and Saravan in Sistan and Balouchestan province which were generated due to activities of uncertainly identified faults and also hidden faults, have clearly shown the need for further investigation of the faults along with more hazard analysis assessments. The studied area includes shorelines which are very important especially from geopolitical, geostrategic and geo-economic vantage point. The registered seismic events in Makran zone and Oman sea along with the tsunami event [2] of November $27^{\text {th }} 1945$ in the Makran coast (with magnitude of 8.2) [1] are proof for unsafety of the region against seismic activities and tsunami hazard.

This region is located in the Makran seismotectonic province, the northern side of which leads to Jazmoorian subsidence, the western side of it is identified with Minab faults, the southern extent ends in Oman sea and the eastern side leads to Pakistan border, albeit it continues after the border (Figure 1) [3]. Towards the northern part of this zone, there are faults and thrusts with eastern-western trend of which Beshagerd fault is the most important. Along the direction of these fractures, colorful mixtures with extended outcrops are evident. The eldest rocks of this zone are these colorful mélanges which are related to upper cretaceous-Paleocene, after them are thick flysch like sediments of Eocene and Oligocene which are comprised of sandstone, shill and marl sequence and are placed on the aforementioned colorful mixtures and their thickness could be as much as 5000 meters. These sediments were folded before the start of Miocene era and Neogene sediment thickness is large and is around 5000 meters. From geological point of view, reference [4], believes that this mountain range is an ancient crust gap which in the form of a side extending prism, from lower cretaceous or lower tertiary to Holocene, located in the upper wall of a shallow mildly dipped subduction zone. In an overall view, height of this mountain range decreases from north to south.

\section{Makran Stratigraphy}

Makran zone is a type of cross-continental separation in the Iran plate with the age of upper Jurassic to lower cretaceous which according to the attributes of the sonar waves and wave speed in the rock bed has created oceanic crust as well. Due to this fact, the rock bed in the region is a type of oceanic crust with mean thickness of about $7 \mathrm{~km}$, which is covered by a thick sequence of flysch like 


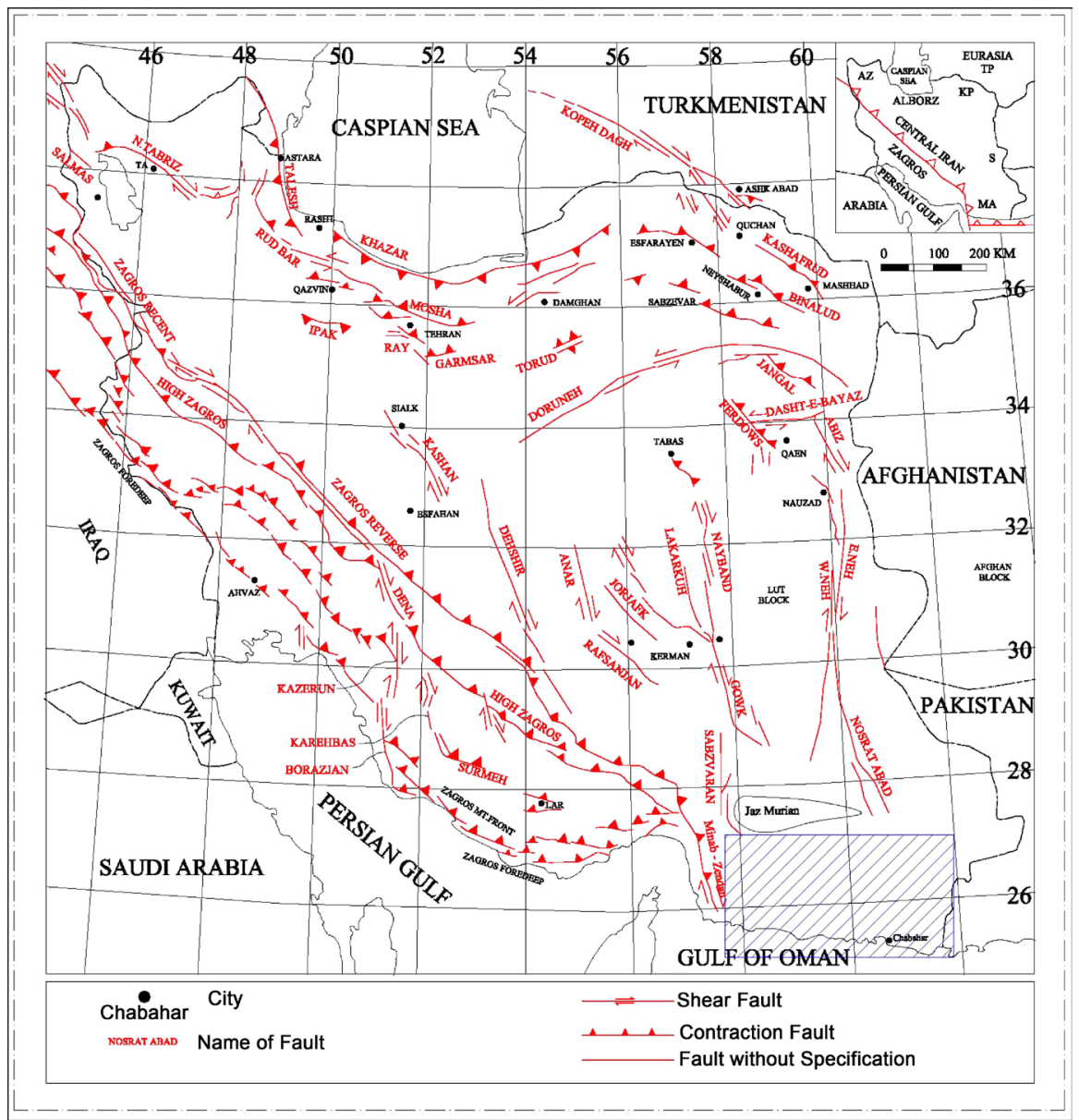

Figure 1. Plan of Iran major faults [5]. The blue hatched box is showing the studied area.

sediments or sometimes pseudo molasses which could be as thick as 10 thousand meters [6]. In the northern part of the Makran region, oceanic crust and upper cretaceous pelagic sediments have outcrops but are covered by or mixed with flysch rows of upper cretaceous-Eocene. In the middle extent of Makran, Oligocene flysches are covered by numerous parallel multi-dipped inter-formations and an angular multi-dipped upper layer. The youngest Makran sediments consist of loose weak cementite sandstones with the age of plié-Pleistocene.

\section{Tectonics}

In Makran, folding has an almost eastern-western trend which conforms to the direction of the maximum shortening and pressure in the north east direction. Shortening is mostly accompanied with thrusting in the way that boundaries between many stratigraphy units are formed by thrust. Considering this, Makran formation has imbricated pattern on which boundaries between imbricates are determined by reverse steep faults and a consequent of which, imbricates are thrust from pre-land (N-NE) to fore-land (S-SW) (Figure 2) [7]. Faults located in the studied area could be categorized based on the time of their creation history and typical role, into three groups. Longitudinal faults whose mechanism 


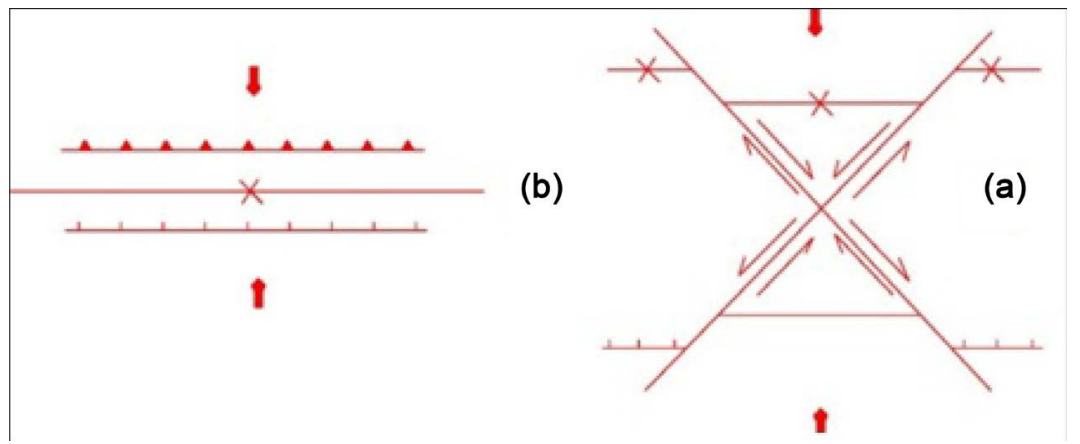

Figure 2. Movement mechanism in Makran longitudinal faults and converging faults. (a) the couple convergent strike slip fault groups; (b) reverse and thrust faults simultaneous with folding [7].

were normal in the beginning when they were generated at the time of basin formation; however, under thrusting regimes which were later imposed on them, they turned into thrusting faults with steep dips directed towards north and northeast. The conjugate faults could be classified into two groups based on their trend and mechanism. The first group has northwest trend and dextral strike slip mechanism. The second group has northeast trend and sinistral strike slip mechanism. Normal faults which could be seen in the Makran coast. Their creation time has been identified as quaternary and it has been accepted that linearity of the marine terrace northern margin and also elevation of the Makran coasts are results of these faults activities and the vertical movement of these faults have led to formation of the marine terraces in different levels [7].

\section{Seismicity}

Regarding seismic activity, Makran could be divided into two parts, eastern and western. Owing to descending plate, the eastern side has been struck by earthquakes with magnitudes ranging from middle to high and middle to surface focal depths (e.g. earthquakes of the years $1765,1851,1945)$ whereas no earthquake has been recorded in the coastal zone of the western Makran except maybe for the massive earthquake of 1483 [1] [8] for which there are no concrete evidence available.

Makran as an active subduction zone generally has a very weak seismicity potential. Reference [9] attributes the absence of earthquake events in the western Makran, to the presence of huge amounts of non-stiffened saturated sediments which have low internal friction angle and therefore they do not have seismic activity. However, presence of marine terraces and 9 mud volcanos is a proof for dynamicity of this region, an evidence of which is the Pasty Urama earthquake of 1945 with the magnitude of 8.3 [1].

\section{Seismic Sources}

In order to identify the most important linear seismic sources in the studied area, available documents, satellite images and in some cases field investigation 
results have been used. In addition to identification of linear seismic sources, subduction zones have been studied as well. The obtained results indicate that there are 81 linear seismic sources along with three subduction zones present in the studied area which contribute to seismic activity of the region, the characteristics of which are presented in the Table 1 and Table 2.

The linear seismic sources of the studied region have different mechanism as well as dip directions in the way that close to the coast, faults generally have normal mechanisms with dip direction towards the south and in the northern parts which have mountain formation, faults generally have reverse mechanisms with dip direction towards the north.

According to the presence of Kuh Sultan volcano (Pakestan), Taftan and Bazman volcanos (Iran), various researchers have come to conclusion that descending plate has ruptured during the subduction process and each part is descending into the mantle separately and under different conditions [10] [11]. According to the above explanation and carried out explorations, three subduction zones A, B and C have been identified in the studied area as influencing the region which are introduced as follows.

Zone A: this zone comprises the western boundary of the studied area and due to mild slope (below 10 degrees) of the descending plate, it does not have the volcanic dynamism. In the studied area an extent as large as 29255 square kilometer is affected by this zone [12].

Zone B: slope of this descending plate is estimated to be about 38 - 50 degrees and unlike Zone A, it has volcanic activity. Due to stark difference between focal depths of earthquakes recorded in the extent of this zone, it has been divided to two segments B1 and B2. Segment B1 includes the extent between surface trace of Makran deformation fault and the line parallel to the shoreline at the distance of 70 kilometers. Area of this segment is 93,612 square kilometers. In this segment, earthquake focal depths are generally shallow. Segment B2 has been separated from segment B1 due to having deeper focal depths and the northern boundary of this extent ends in the volcanic arc. Area of this seismic segment in the studied region is 3578 square kilometers [12].

Zone C: like zone $\mathrm{B}$, this zone has volcanic activity as well and constitutes the eastern part of the studied area. Descending plate dip in this extent is estimated to be about 19 - 28 degrees [12].

It should be noted that based on the assembled earthquake catalogue of the

Table 1. Subduction zones available in the studied region along with their respective areas and mechanisms.

\begin{tabular}{ccccc}
\hline Row & Subduction zone & Mechanism & Area $\left(\mathrm{km}^{2}\right)$ & $\mathrm{Mw}$ \\
\hline 1 & A & & 29,255 & 7.7 \\
2 & B1 & Reverse & 93,612 & 6.1 \\
3 & B2 & 3578 & 7.7 \\
4 & C & & 12,617 & 8.3 \\
\hline
\end{tabular}


Table 2. Faults available in the studied region with length greater than 10 kilometer, along with their respective lengths and mechanisms (N: normal fault, R: reverse or thrust fault, S: strike slip fault).

\begin{tabular}{|c|c|c|c|c|}
\hline Row & Faults Name & Mechanism & Dip Direction & Length of fault $(\mathrm{Km})$ \\
\hline 1 & Ahvan & $\mathrm{R}$ & S-SW & 19 \\
\hline 2 & Band_e_kalaf & S & - & 12 \\
\hline 3 & Bashakerd 1 & $\mathrm{~T}$ & NE-NW & 53 \\
\hline 4 & Bashakerd 2 & $\mathrm{R}$ & N-NE-NW & 26 \\
\hline 5 & Bashakerd 3 & $\mathrm{R}$ & N-NE-NW & 57 \\
\hline 6 & Bashakerd 4 & $\mathrm{R}$ & $\mathrm{N}$ & 28 \\
\hline 7 & Bir 1 & $\mathrm{~N}$ & Sw-S-SE & 22 \\
\hline 8 & Chan Khan 1 & $\mathrm{~T}$ & NW & 109 \\
\hline 9 & Chan Khan 2 & $\mathrm{~T}$ & N-NW & 150 \\
\hline 10 & Chanf & $\mathrm{T}$ & N-NW-NE & 162 \\
\hline 11 & Chekkeh & $\mathrm{N}$ & S-SW-SE & 19 \\
\hline 12 & Cheshmeh_reshki & $\mathrm{N}$ & $\mathrm{SE}$ & 16 \\
\hline 13 & Dar Anar & $\mathrm{R}$ & $\mathrm{NE}$ & 35 \\
\hline 14 & Darhaman Fault & S & - & 17 \\
\hline 15 & Darmail1 & $\mathrm{R}$ & S & 32 \\
\hline 16 & Darmail2 & $\mathrm{R}$ & SW & 35 \\
\hline 17 & Dazi Fault & $\mathrm{T}$ & SW & 31 \\
\hline 18 & De_gonir & $\mathrm{R}$ & $\mathrm{NE}$ & 26 \\
\hline 19 & Durky & $\mathrm{N}$ & Sw & 12 \\
\hline 20 & East Sahran & $\mathrm{N}$ & SW & 13 \\
\hline 21 & Firuz Abad 1 & $\mathrm{~T}$ & N-NW & 92 \\
\hline 22 & Firuz abad 2 & $\mathrm{~T}$ & N-NW & 47 \\
\hline 23 & Gabik & $\mathrm{R}$ & N-NE-NW & 26 \\
\hline 24 & Gabrik & $\mathrm{R}$ & $\mathrm{NE}$ & 53 \\
\hline 25 & Gahmuh & $\mathrm{R}$ & N-NE-NW & 49 \\
\hline 26 & Gakosh & $\mathrm{R}$ & N-NE-NW & 56 \\
\hline 27 & Garu Char & $\mathrm{R}$ & N-NW-NE & 36 \\
\hline 28 & Gativan 1 & $\mathrm{~T}$ & N-NW & 168 \\
\hline 29 & Gativan 2 & $\mathrm{~T}$ & NE-NW & 71 \\
\hline 30 & Gative & $\mathrm{N}$ & S & 13 \\
\hline 31 & Gava & $\mathrm{N}$ & SE & 11 \\
\hline 32 & Gaz & $\mathrm{R}$ & $\mathrm{N}$ & 40 \\
\hline 33 & Gazidir & $\mathrm{N}$ & Sw & 11 \\
\hline 34 & Geeshkan & S & - & 15 \\
\hline 35 & Ghasre Ghand 1 & $\mathrm{~T}$ & N-NW & 92 \\
\hline
\end{tabular}




\section{Continued}

\begin{tabular}{|c|c|c|c|c|}
\hline 36 & Ghasr Ghand 2 & $\mathrm{~T}$ & N-NW & 84 \\
\hline 37 & Ghasre Ghand 3 & $\mathrm{~T}$ & N-NW & 91 \\
\hline 38 & Gonz Fault & $\mathrm{N}$ & SW-s-SE & 18 \\
\hline 39 & Gozer fault & $\mathrm{N}$ & S-SE-S & 32 \\
\hline 40 & Hangestan & $\mathrm{N}$ & $S$ & 39 \\
\hline 41 & Jaghin & $\mathrm{R}$ & $\mathrm{NE}$ & 37 \\
\hline 42 & Jagin & $\mathrm{N}$ & S & 26 \\
\hline 43 & Jahlizak & $\mathrm{R}$ & S-SE-SW & 49 \\
\hline 44 & Kahir & $\mathrm{N}$ & S-SE-SW & 33 \\
\hline 45 & Kahorkan 1 & $\mathrm{~T}$ & NE-NW & 79 \\
\hline 46 & Kahorkan 2 & $\mathrm{R}$ & N-NW-NE & 29 \\
\hline 47 & Kajeh & $\mathrm{T}$ & N-NW & 100 \\
\hline 48 & Kalemi & $\mathrm{R}$ & S-SE & 24 \\
\hline 49 & Kanas & $\mathrm{R}$ & N-NW-NE & 20 \\
\hline 50 & Kashi & $\mathrm{N}$ & SE & 11 \\
\hline 51 & Johidarak & $\mathrm{N}$ & $S$ & 20 \\
\hline 52 & Khodar & $\mathrm{R}$ & $\mathrm{N}$ & 27 \\
\hline 53 & Kuh Boland & $\mathrm{T}$ & $\mathrm{E}$ & 12 \\
\hline 54 & Kuh-e-Gar & $\mathrm{R}$ & NW-N-NE & 25 \\
\hline 55 & Kundar & $\mathrm{R}$ & $\mathrm{NE}$ & 23 \\
\hline 56 & Lakini & $\mathrm{N}$ & SW-S & 10 \\
\hline 57 & Lashar & $\mathrm{T}$ & NE-NW & 50 \\
\hline 58 & Lireii & $\mathrm{N}$ & S & 14 \\
\hline 59 & Malkamu 1 & $\mathrm{~N}$ & SW & 28 \\
\hline 60 & Malkamu 2 & $\mathrm{~N}$ & S & 49 \\
\hline 61 & Mashgahem & $\mathrm{T}$ & N-NE-NW & 13 \\
\hline 62 & MOMAN 1 & $\mathrm{~N}$ & S & 32 \\
\hline 63 & Morton & $\mathrm{R}$ & $\mathrm{N}$ & 73 \\
\hline 64 & Negar_baluchi & $\mathrm{N}$ & S & 10 \\
\hline 65 & Pashgiram 1 & $\mathrm{R}$ & $\mathrm{NE}$ & 28 \\
\hline 66 & Pashgiram 2 & $\mathrm{R}$ & $\mathrm{NE}$ & 35 \\
\hline 67 & Pip & $\mathrm{R}$ & NW & 48 \\
\hline 68 & Pishamak & $\mathrm{T}$ & N-NW & 90 \\
\hline 69 & Pouzak & $\mathrm{N}$ & $\mathrm{NE}$ & 34 \\
\hline 70 & Sabz & $\mathrm{R}$ & $\mathrm{N}-\mathrm{Nw}$ & 13 \\
\hline 71 & Sagar 1 & $\mathrm{~N}$ & SW & 20 \\
\hline 72 & Sagar 2 & $\mathrm{~N}$ & SW & 11 \\
\hline 73 & Sarani & $\mathrm{N}$ & S & 24 \\
\hline
\end{tabular}




\begin{tabular}{|c|c|c|c|c|}
\hline \multicolumn{5}{|c|}{ Continued } \\
\hline 74 & Sedich & $\mathrm{N}$ & S & 11 \\
\hline 75 & Shame sar & $\mathrm{N}$ & S-SE-Sw & 12 \\
\hline 76 & Shoski & $\mathrm{N}$ & S & 25 \\
\hline 77 & Siromch & S & $\mathrm{E}$ & 10 \\
\hline 78 & Sohran & $\mathrm{N}$ & W-SW & 10 \\
\hline 79 & Veranj & $\mathrm{R}$ & N-N-NE & 30 \\
\hline 80 & Zaur & $\mathrm{N}$ & SW & 11 \\
\hline 81 & Zirdan & $\mathrm{N}$ & S-SE-Sw & 72 \\
\hline
\end{tabular}

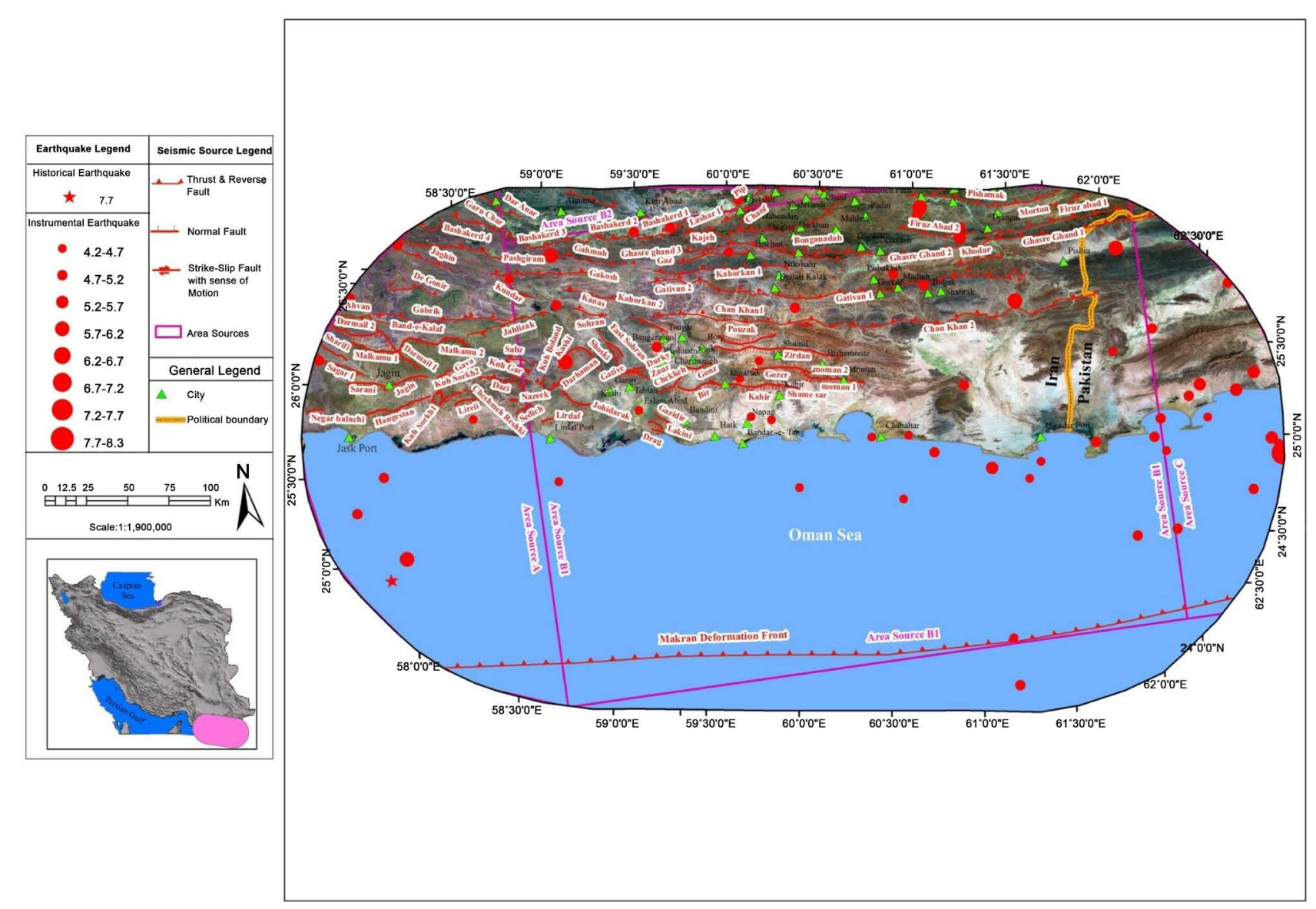

Figure 3. Plan of linear and are seismic sources in the studied area.

region, the maximum magnitude of earthquakes recorded in the subduction zones $\mathrm{A}, \mathrm{B} 1, \mathrm{~B} 2$ and $\mathrm{C}$ is 7.7, 6.1, 7.7 and 8.1 respectively.

\section{Modelling}

As was mentioned in the previous sections, the studied area is located in an active subduction zone and dense surface faulting has been observed in the northern part of it. Since the contribution ratio of the subduction plates and surface faults is not determined, in order to assess the seismic hazard of the region, three 
different approaches have been considered. The first approach is to attribute all the earthquakes happened in the region to the surface faults. Based on this assumption, the activity rate obtained from analysis of the earthquake catalogue is completely assigned to the linear seismic sources. The second approach is related to the subduction zone and all earthquakes have been attributed to it and therefore, the calculated activity rate is assigned to the subduction model. On the other hand, should the activity rate be divided between subduction model and surface faults with different ratios, the values of the maximum strong ground motion will be between the values obtained using two aforementioned approaches. Results of this assessment are investigated in 12 points inside the studied area (Figure 4) and the criterion behind selection of these points was to span all northern, middle and southern parts of the studied area (Figures 5-16 and Tables 3-14). According to the investigation results, in some parts of the region, linear seismic sources are sparse which results in higher maximum strong motion values in comparison with surface faulting model (southern to middle extent). However, in close proximity of the faults, surface faulting model (northern extent) yields higher values. It should be noted that in the tables presented in this article, contribution ration percentage of two seismic models are

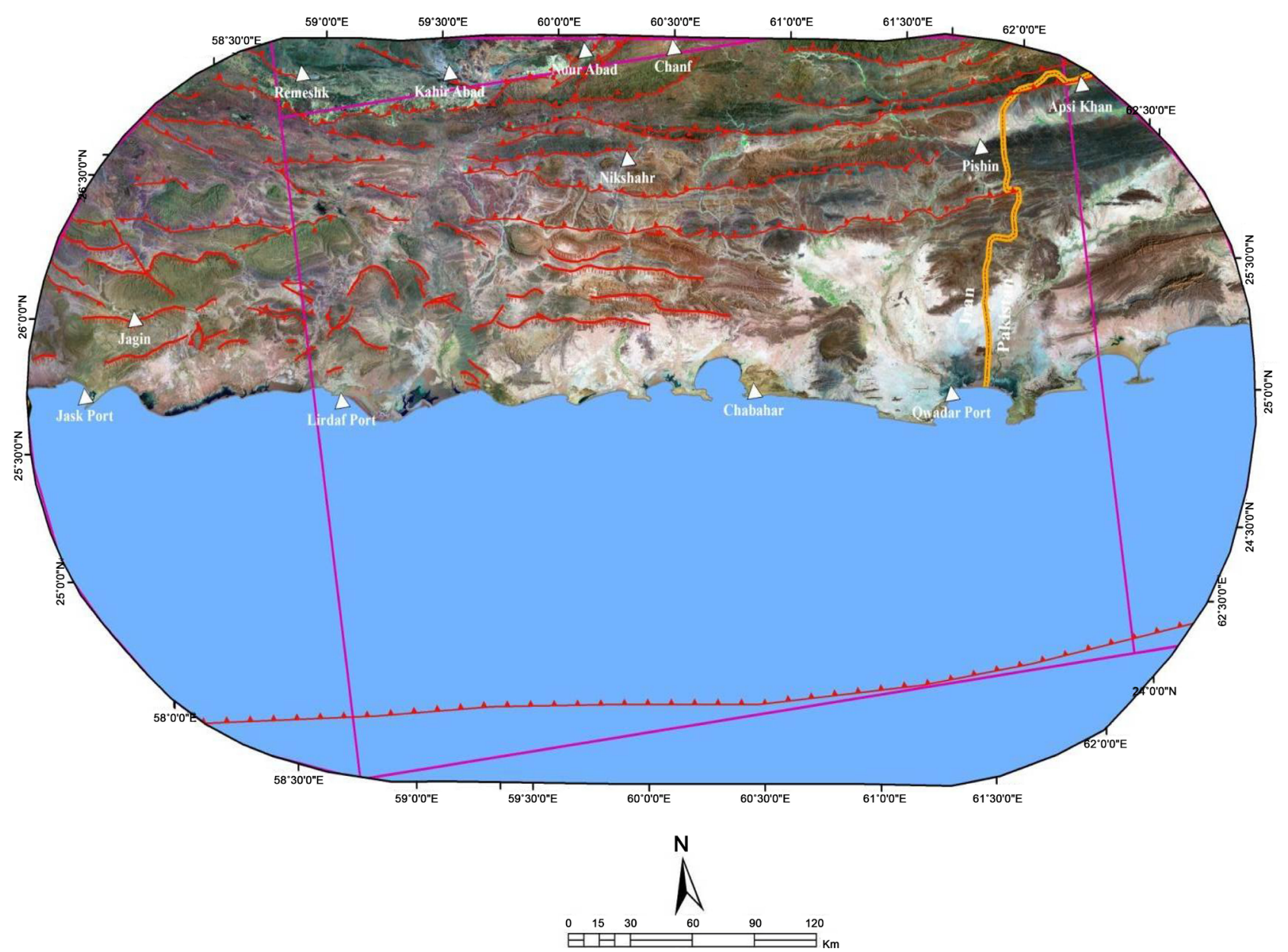

Figure 4. Location of the investigated points. 
Table 3. Results of surface faulting and subduction models along with the intermediate state for Gwadar Port.

\begin{tabular}{cccc}
\hline \multirow{2}{*}{1} & \multicolumn{3}{c}{ Gwadar Port } \\
\cline { 2 - 4 } $0 \%$ & 500 & 1000 & 2000 \\
\hline $10 \%$ & 0.37389 & 0.50414 & 0.65716 \\
$20 \%$ & 0.35602 & 0.48263 & 0.63128 \\
$30 \%$ & 0.33699 & 0.45914 & 0.60348 \\
$40 \%$ & 0.31665 & 0.4339 & 0.57344 \\
$50 \%$ & 0.29396 & 0.40648 & 0.54061 \\
$60 \%$ & 0.26684 & 0.37396 & 0.5042 \\
$70 \%$ & 0.23704 & 0.33702 & 0.45915 \\
$80 \%$ & 0.19745 & 0.28791 & 0.39811 \\
$90 \%$ & 0.15786 & 0.23717 & 0.33706 \\
$100 \%$ & 0.10303 & 0.15887 & 0.23744 \\
& 0.03958 & 0.05132 & 0.06346 \\
\hline
\end{tabular}

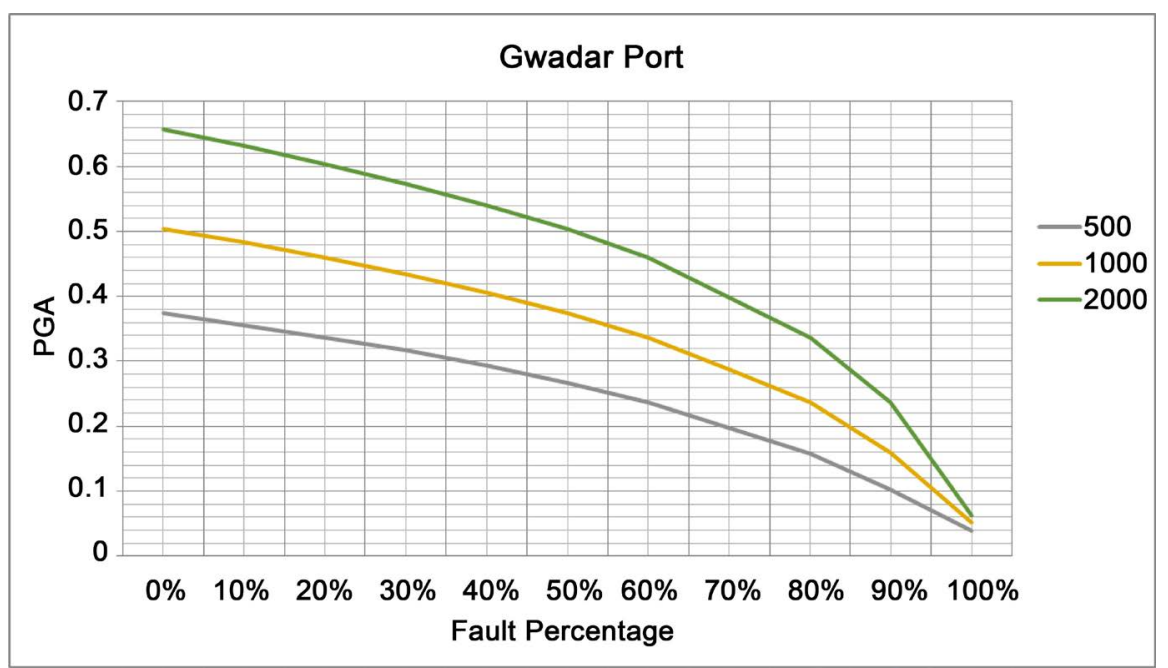

Figure 5. Interaction of subduction and surface fault effects in Gwadar port.

Table 4. Results of surface faulting and subduction models along with the intermediate state for Chabahar city.

\begin{tabular}{cccc}
\hline 2 & \multicolumn{3}{c}{ Chabahar } \\
\cline { 2 - 4 } $0 \%$ & 500 & 1000 & 2000 \\
\hline $10 \%$ & 0.37856 & 0.5084 & 0.66182 \\
$20 \%$ & 0.3607 & 0.48738 & 0.63595 \\
$30 \%$ & 0.34171 & 0.4639 & 0.60816 \\
$40 \%$ & 0.32143 & 0.4387 & 0.57815 \\
$50 \%$ & 0.29953 & 0.41135 & 0.54537 \\
$60 \%$ & 0.27271 & 0.3795 & 0.50905 \\
$70 \%$ & 0.24344 & 0.34291 & 0.46475 \\
$80 \%$ & 0.20618 & 0.2906 & 0.40486 \\
$90 \%$ & 0.16891 & 0.2463 & 0.34496 \\
$100 \%$ & 0.12261 & 0.1784 & 0.2531 \\
\hline
\end{tabular}






Figure 6. Interaction of subduction and surface fault effects in Chabahr city.

Table 5. Results of surface faulting and subduction models along with the intermediate state for Lirdaf Port.

\begin{tabular}{cccc}
\hline 3 & \multicolumn{3}{c}{ Lirdaf Port } \\
\cline { 2 - 4 } $0 \%$ & 500 & 1000 & 2000 \\
\hline $10 \%$ & 0.37414 & 0.50347 & 0.65559 \\
$20 \%$ & 0.35723 & 0.48283 & 0.63064 \\
$30 \%$ & 0.33935 & 0.46048 & 0.60394 \\
$40 \%$ & 0.32041 & 0.43662 & 0.57524 \\
$50 \%$ & 0.30018 & 0.41093 & 0.54409 \\
$60 \%$ & 0.27583 & 0.38142 & 0.50987 \\
$70 \%$ & 0.24974 & 0.34807 & 0.46893 \\
$80 \%$ & 0.21976 & 0.30713 & 0.41642 \\
$90 \%$ & 0.18978 & 0.26618 & 0.36391 \\
$100 \%$ & 0.15278 & 0.2142 & 0.29252 \\
& 0.1161 & 0.15353 & 0.20268 \\
\hline
\end{tabular}

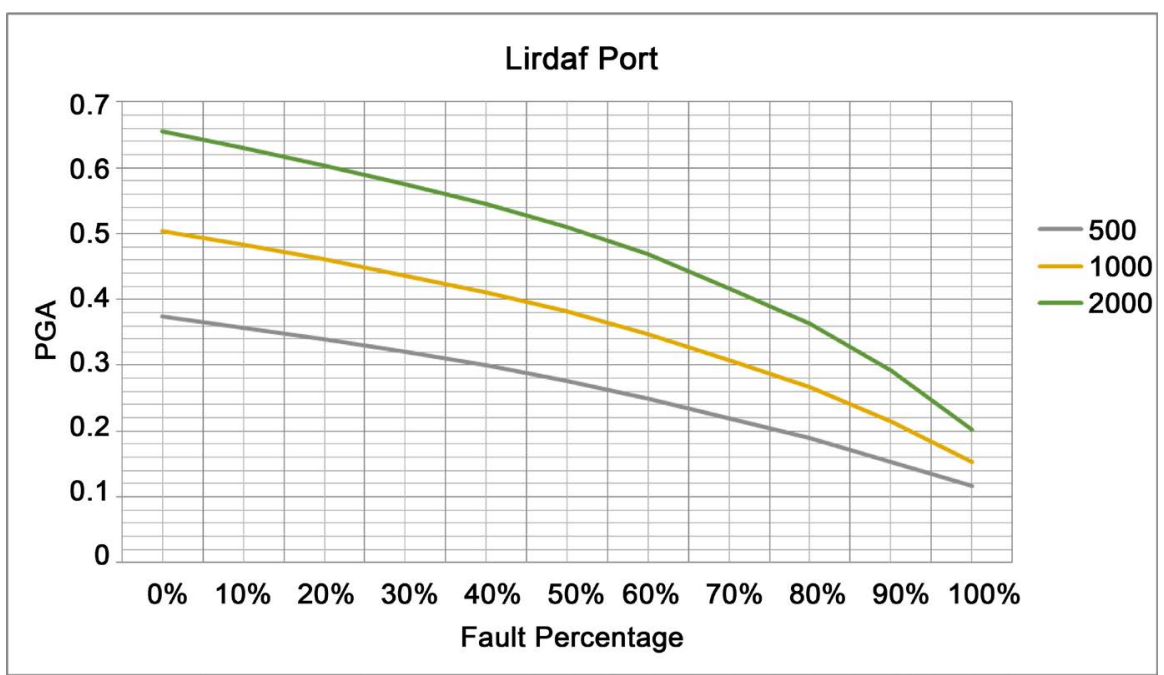

Figure 7. Interaction of subduction and surface fault effects in Lirdaf port. 
Table 6. Results of surface faulting and subduction models along with the intermediate state for Kahir Abad.

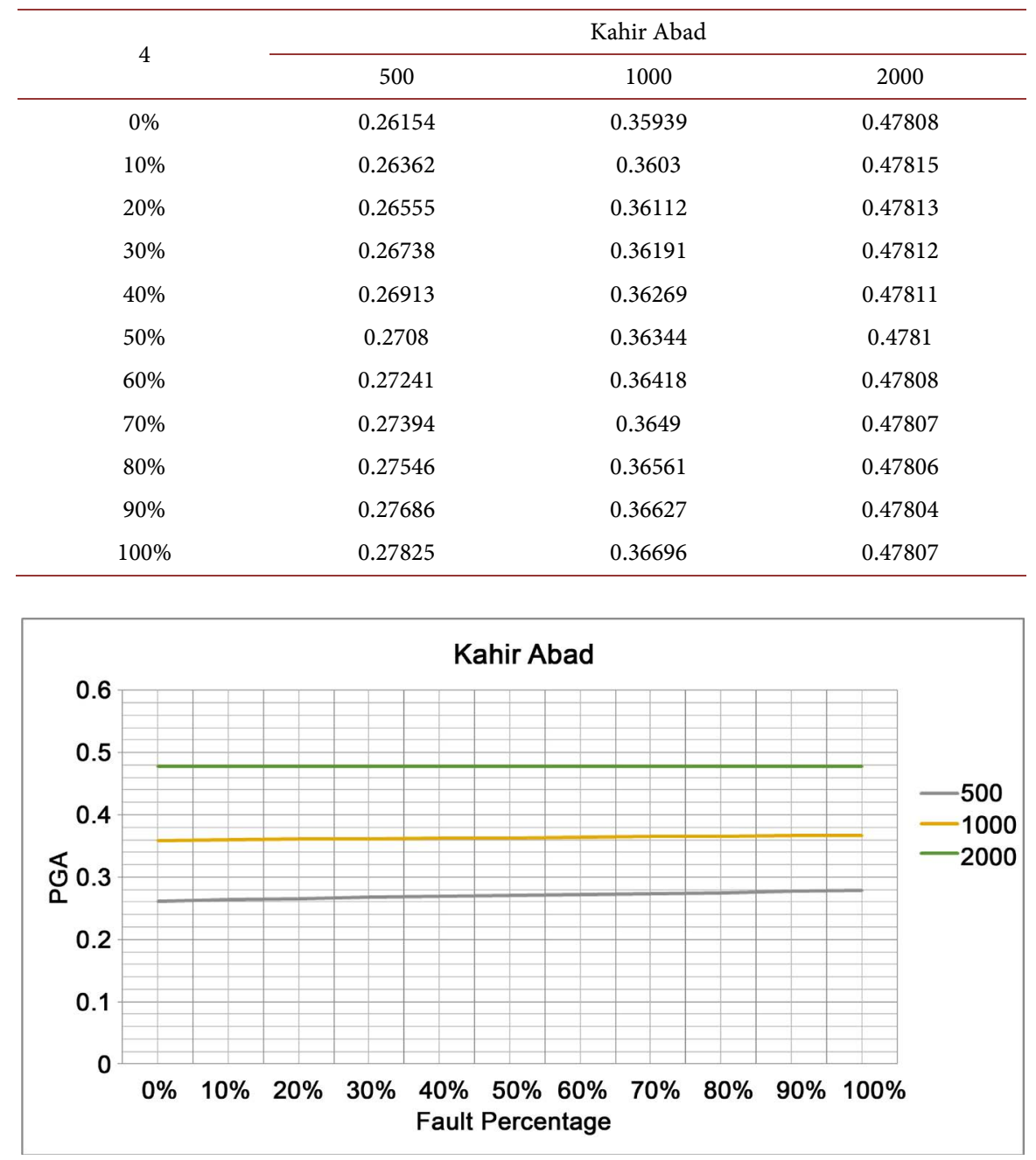

Figure 8. Interaction of subduction and surface fault effects in Kahir Abad.

Table 7. Results of surface faulting and subduction models along with the intermediate state for Chanf city.

\begin{tabular}{cccc}
\hline 5 & & Chanf & \\
\cline { 2 - 4 } $0 \%$ & 500 & 1000 & 2000 \\
\hline $10 \%$ & 0.26663 & 0.37 & 0.49596 \\
$20 \%$ & 0.27205 & 0.37544 & 0.5019 \\
$30 \%$ & 0.27715 & 0.38064 & 0.50732 \\
$40 \%$ & 0.28201 & 0.38568 & 0.51265 \\
$50 \%$ & 0.28667 & 0.39059 & 0.51792 \\
$60 \%$ & 0.29113 & 0.39535 & 0.52311 \\
$70 \%$ & 0.29542 & 0.39999 & 0.52824 \\
$80 \%$ & 0.29936 & 0.4042 & 0.53327 \\
$90 \%$ & 0.3033 & 0.4084 & 0.53829 \\
$100 \%$ & 0.30693 & 0.4125 & 0.54322 \\
\hline
\end{tabular}




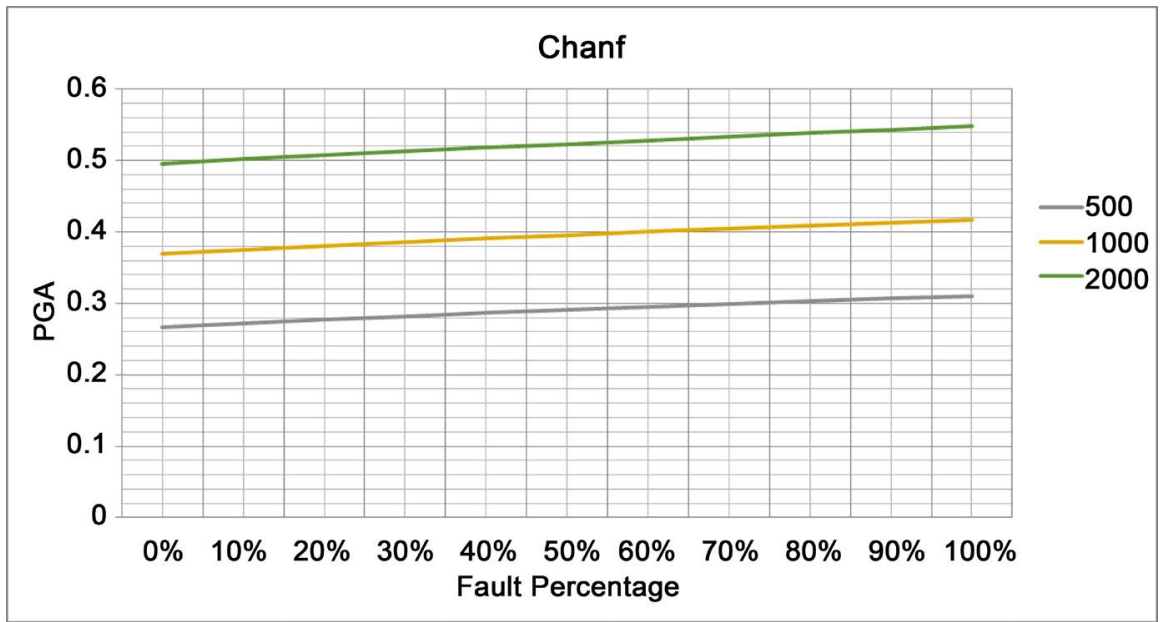

Figure 9. Interaction of subduction and surface fault effects in Chanf city.

Table 8. Results of surface faulting and subduction models along with the intermediate state for Nikshahr city.

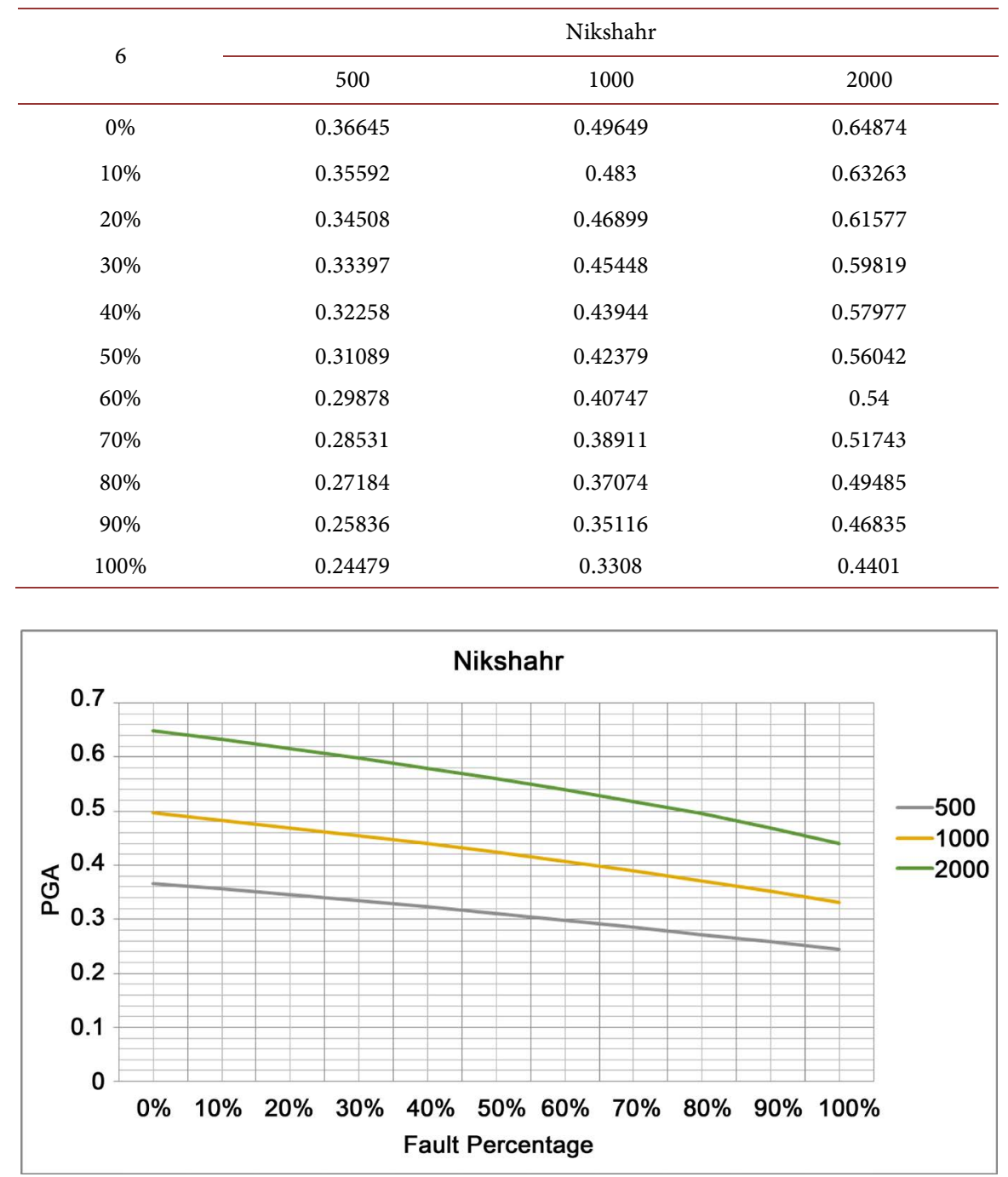

Figure 10. Interaction of subduction and surface fault effects in Nikshahr city. 
Table 9. Results of surface faulting and subduction models along with the intermediate state for Pishin city.

\begin{tabular}{cccc}
\hline 7 & \multicolumn{3}{c}{ Pishin } \\
\cline { 2 - 4 } $0 \%$ & 500 & 1000 & 2000 \\
\hline $10 \%$ & 0.35745 & 0.48709 & 0.63929 \\
$20 \%$ & 0.34411 & 0.47002 & 0.61856 \\
$30 \%$ & 0.33025 & 0.45215 & 0.59671 \\
$40 \%$ & 0.31587 & 0.43346 & 0.5737 \\
$50 \%$ & 0.30094 & 0.41385 & 0.54933 \\
$60 \%$ & 0.28354 & 0.39254 & 0.5234 \\
$70 \%$ & 0.26552 & 0.36872 & 0.49517 \\
$80 \%$ & 0.24668 & 0.34293 & 0.46105 \\
$90 \%$ & 0.22784 & 0.31714 & 0.42692 \\
$100 \%$ & 0.20834 & 0.288 & 0.3876 \\
\hline
\end{tabular}

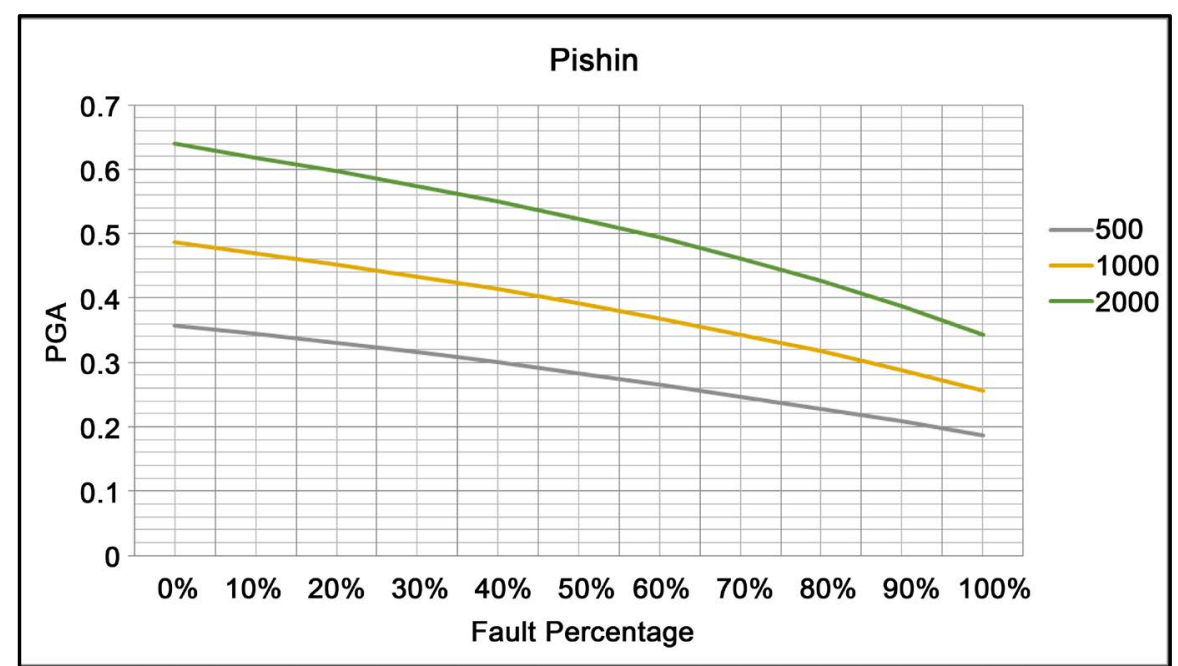

Figure 11. Interaction of subduction and surface fault effects in Pishin city.

Table 10. Results of surface faulting and subduction models along with the intermediate state for Nour Abad.

\begin{tabular}{cccc}
\hline \multirow{2}{*}{5} & & Nour Abad & \\
\cline { 2 - 3 } $0 \%$ & 500 & 1000 & 2000 \\
$10 \%$ & 0.25252 & 0.34915 & 0.46639 \\
$20 \%$ & 0.27169 & 0.36969 & 0.48897 \\
$30 \%$ & 0.28857 & 0.38803 & 0.50866 \\
$40 \%$ & 0.30341 & 0.4044 & 0.52605 \\
$50 \%$ & 0.31598 & 0.41872 & 0.5423 \\
$60 \%$ & 0.32763 & 0.43209 & 0.5576 \\
$70 \%$ & 0.33853 & 0.44466 & 0.57206 \\
$80 \%$ & 0.34852 & 0.45624 & 0.58548 \\
$90 \%$ & 0.3585 & 0.46782 & 0.5989 \\
$100 \%$ & 0.36774 & 0.47858 & 0.61144 \\
\hline
\end{tabular}




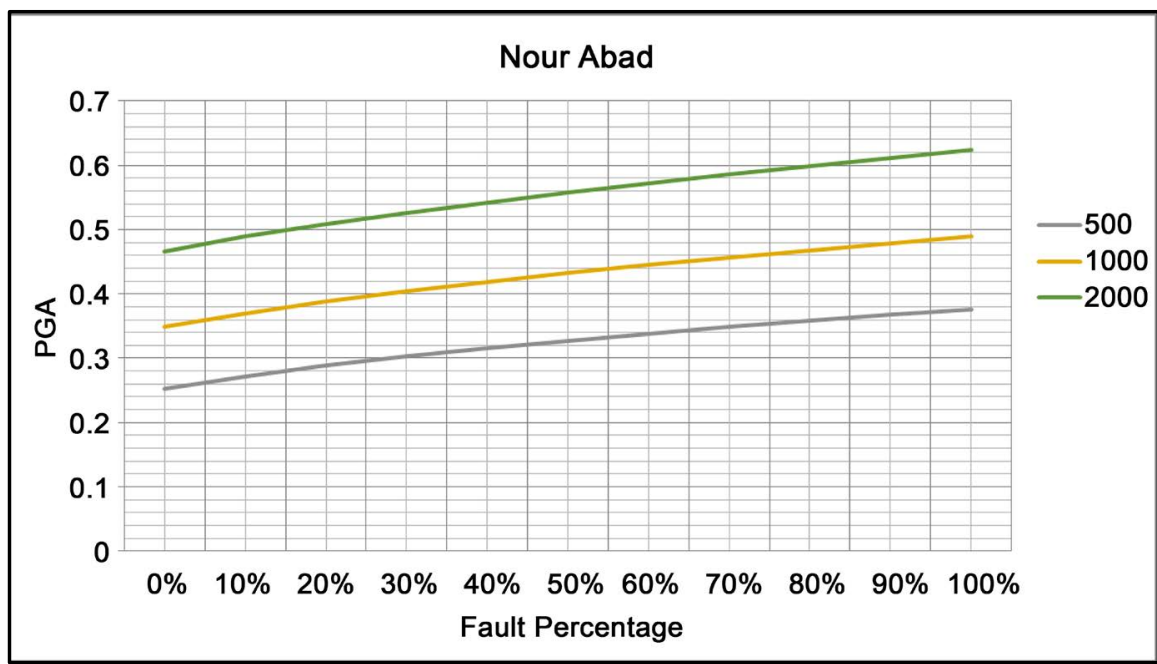

Figure 12. Interaction of subduction and surface fault effects in Nour Abad.

Table 11. Results of surface faulting and subduction models along with the intermediate state for Remeshk city.

\begin{tabular}{cccc}
\hline 9 & & Remeshk & \\
\cline { 2 - 4 } $0 \%$ & 500 & 1000 & 2000 \\
\hline $10 \%$ & 0.25359 & 0.34905 & 0.46439 \\
$20 \%$ & 0.25799 & 0.35364 & 0.4697 \\
$30 \%$ & 0.2622 & 0.35807 & 0.47485 \\
$40 \%$ & 0.26625 & 0.36239 & 0.47993 \\
$50 \%$ & 0.27017 & 0.36661 & 0.48491 \\
$60 \%$ & 0.27397 & 0.37073 & 0.48982 \\
$70 \%$ & 0.27765 & 0.37477 & 0.49465 \\
$80 \%$ & 0.28812 & 0.37868 & 0.49924 \\
$90 \%$ & 0.2847 & 0.38259 & 0.50383 \\
$100 \%$ & 0.28808 & 0.38638 & 0.50816 \\
\hline & 0.29149 & 0.39024 & 0.51263 \\
\hline
\end{tabular}



Figure 13. Interaction of subduction and surface fault effects in Remeshk city. 
Table 12. Results of surface faulting and subduction models along with the intermediate state for Jask Port.

\begin{tabular}{cccc}
\hline \multirow{2}{*}{10} & \multicolumn{3}{c}{ Jask Port } \\
\cline { 2 - 4 } & 500 & 1000 & 2000 \\
\hline $10 \%$ & 0.3402 & 0.46666 & 0.61653 \\
$20 \%$ & 0.32428 & 0.44658 & 0.59236 \\
$30 \%$ & 0.30753 & 0.42528 & 0.56658 \\
$40 \%$ & 0.28845 & 0.40257 & 0.5389 \\
$50 \%$ & 0.2673 & 0.3761 & 0.5089 \\
$60 \%$ & 0.24498 & 0.34735 & 0.47357 \\
$70 \%$ & 0.22128 & 0.31608 & 0.43355 \\
$80 \%$ & 0.19348 & 0.27781 & 0.3859 \\
$90 \%$ & 0.16529 & 0.23759 & 0.33154 \\
$100 \%$ & 0.13538 & 0.191 & 0.26353 \\
& 0.1073 & 0.14073 & 0.18458 \\
\hline
\end{tabular}

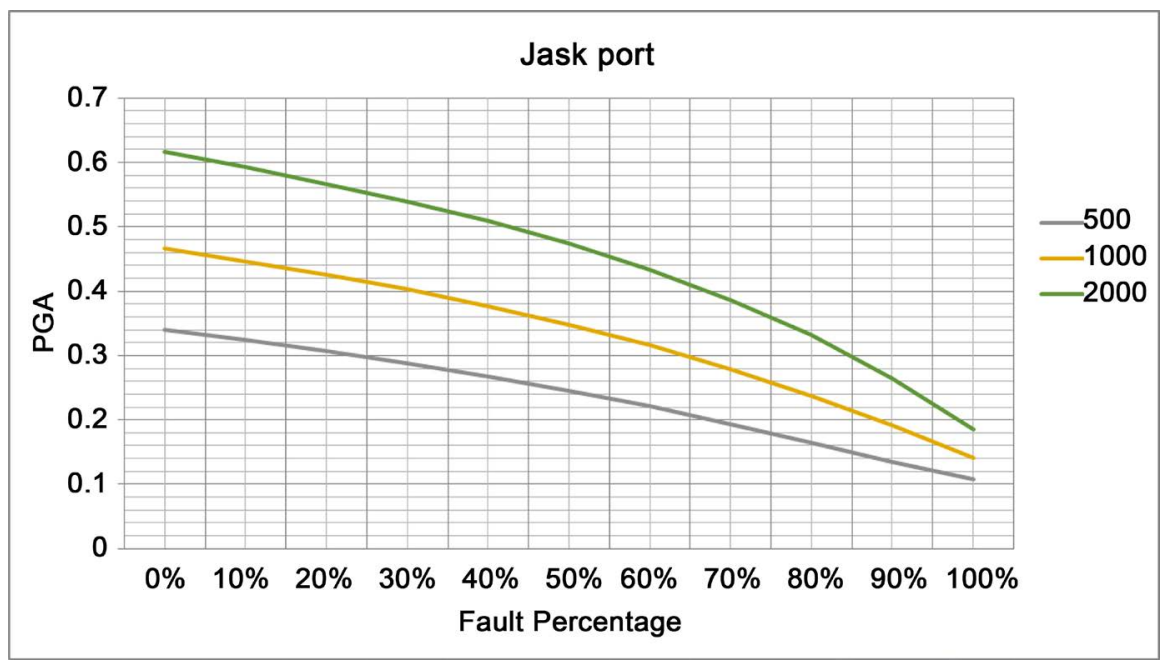

Figure 14. Interaction of subduction and surface fault effects in Jask port.

Table 13. Results of surface faulting and subduction models along with the intermediate state for Jagin city.

\begin{tabular}{cccc}
\hline 11 & \multicolumn{3}{c}{ Jagin } \\
\cline { 2 - 4 } & 500 & 1000 & 2000 \\
\hline $10 \%$ & 0.35843 & 0.48723 & 0.6387 \\
$20 \%$ & 0.34699 & 0.47214 & 0.62008 \\
$30 \%$ & 0.33528 & 0.45654 & 0.60067 \\
$40 \%$ & 0.32333 & 0.44042 & 0.5804 \\
$50 \%$ & 0.31112 & 0.42374 & 0.55918 \\
$60 \%$ & 0.29849 & 0.40644 & 0.53689 \\
$70 \%$ & 0.28442 & 0.38755 & 0.51339 \\
$80 \%$ & 0.26851 & 0.36572 & 0.48561 \\
$90 \%$ & 0.25622 & 0.34711 & 0.45919 \\
$100 \%$ & 0.24221 & 0.32617 & 0.42943 \\
& 0.22832 & 0.30481 & 0.39805 \\
\hline
\end{tabular}




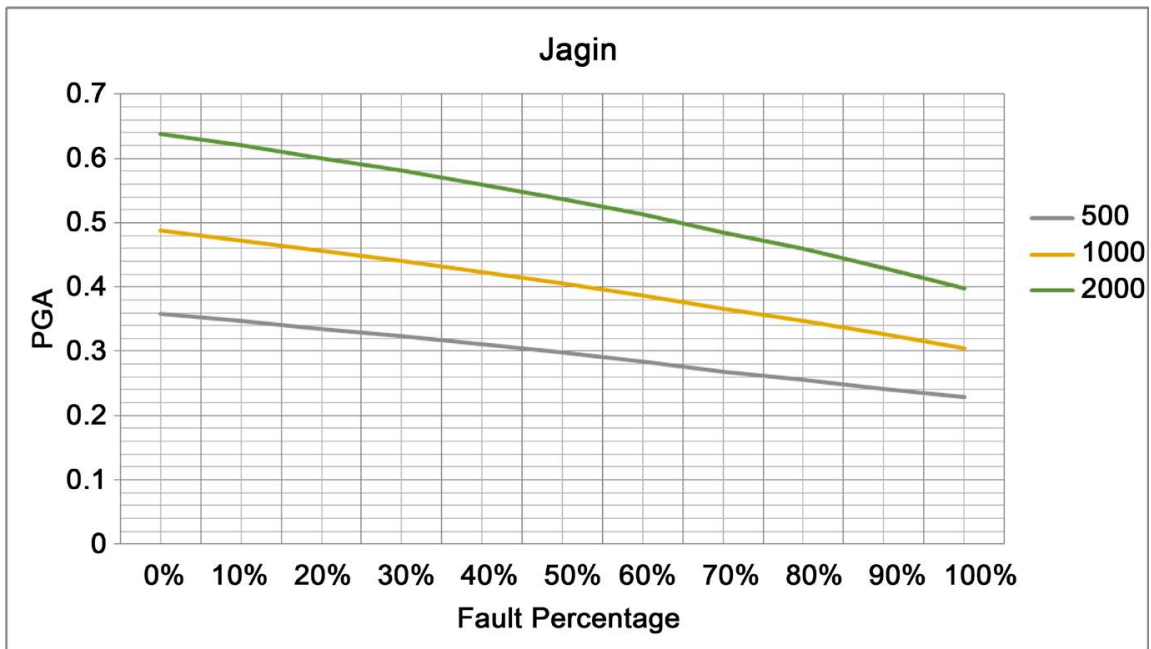

Figure 15. Interaction of subduction and surface fault effects in Jagin city.

Table 14. Results of surface faulting and subduction models along with the intermediate state for Apsi Khan City.

\begin{tabular}{cccc}
\hline \multirow{2}{*}{12} & \multicolumn{3}{c}{ Apsi Kahn } \\
\cline { 2 - 4 } $0 \%$ & 500 & 1000 & 2000 \\
\hline $10 \%$ & 0.25924 & 0.3654 & 0.49597 \\
$20 \%$ & 0.24649 & 0.34876 & 0.4748 \\
$30 \%$ & 0.23331 & 0.33129 & 0.45237 \\
$40 \%$ & 0.21971 & 0.31293 & 0.42853 \\
$50 \%$ & 0.20568 & 0.29283 & 0.40302 \\
$60 \%$ & 0.18995 & 0.27031 & 0.37357 \\
$70 \%$ & 0.17346 & 0.24688 & 0.34168 \\
$80 \%$ & 0.15735 & 0.222 & 0.3047 \\
$90 \%$ & 0.14124 & 0.19712 & 0.26771 \\
$100 \%$ & 0.12611 & 0.16997 & 0.22638 \\
& 0.11209 & 0.14383 & 0.18456 \\
\hline
\end{tabular}

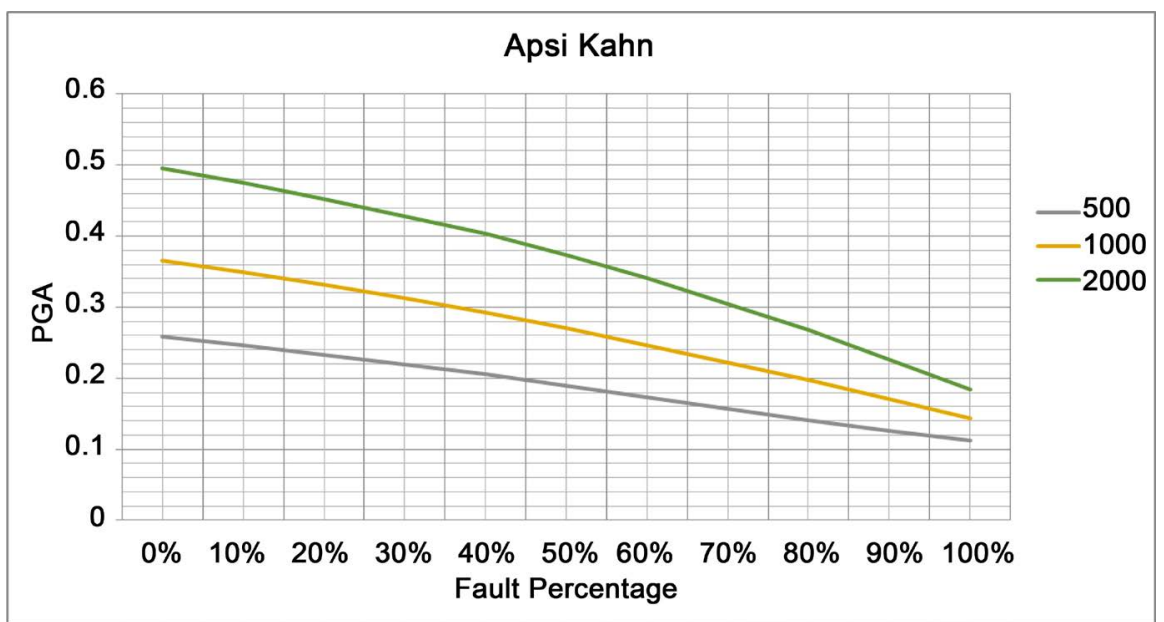

Figure 16. Interaction of subduction and surface fault effects in Apsi Khan City. 
indicated based on surface faulting model contribution, meaning that when it is set to zero percent, subduction model contribution is 100 percent. In order to conduct the maximum strong ground motion value hazard analysis in the studied are, 81 linear seismic sources (faults) along with 4 subduction zones were identified and in order to estimate the horizontal acceleration induced by linear seismic sources, the following attenuation equations were used: Ambraseys 2005 [13];Campbell and Bozorgnia 2008 [14]; Boore and Atkinson 2008 [15]; Chiuo and Youngs 2008 [16] and Abrahamson and Sillva 2008 [17]; and also attenuation equations Young 1997 [18];Atkinson-Boore 2008 [19] were used to estimate the horizontal acceleration induced by subduction model. It should be noted that software package EZ-FRISK 7.52 was used to carry out hazard analysis.

\section{Discussion of Results and Final Conclusion}

In order to assess the seismic hazard in the extent of Makran seismotectonic province, owing to the presence of linear seismic sources along with subduction zones in the region, three different approaches have been taken to develop the seismic model. The first approach assumes that all earthquakes recorded in the studied area are generated by surface faulting activity. According to this hypothesis, the entire activity rate derived based on earthquake catalogue assessment is assigned to the linear seismic sources. The second approach is related to the subduction zone and all earthquake events happened in the region have been attributed to the subduction zone, hence total activity rate was allocated to the subduction model. The third approach is based on the notion that both of these source types contribute simultaneously to the seismicity and the seismic rate has been attributed to each of the sources with various ratios. The results clearly show that in case of separate analysis, the obtained values are conservative estimates of the actual ones and when these two seismic models are considered simultaneously with different distribution of contribution factors, the results will be between those two states. The maximum value of the surface faulting is observed in the northern part of the studied area where the fault density is high. However, in the coastal and middle areas, subduction model gives the maximum values of strong ground motion parameters. In order to obtain even more accurate data on the material discussed in this paper, it is strongly recommended that a comprehensive paleoseismology study along with an extensive geophysical investigation be carried out through the fault traces and also the subduction lines of influence.

\section{References}

[1] Ambraseys, N.N. and Melville, C.P. (1982) A History of Persian Earthquakes. Cambridge University Press, Cambridge.

[2] Rabinovich, A.B., Geist, E.L. and Fritz, H.M. (2015) Introduction to "Tsunami Science: Ten Years after the 2004 Indian Ocean Tsunami. Volume I". Pure and Applied Geophysics, 172, 615. https://doi.org/10.1007/s00024-015-1038-5

[3] Aghanabati, A. (2006) Geology of Iran. Geological Survey, Iran.

[4] Stocklin, J. (1974) Lexique Stratigraphique Internatonal. Vol. III., Fascicule 9b, Iran. 
[5] Berberian, M. and Ashjai, M. (1977) Seismic Risk Map of Iran.

[6] Glennie, K.W., Clarke, M.W.H., Boeuf, M.G.A., Pilar, W.F.H. and Reinhardt, B.M. (1990) Interrelationship of Makran-Oman Mountains Belt of Convergence. In: Robertson, A.H.F., Searle, M.P. and Ries, A.C., Eds., The Geology and Tectonics of the Oman Region, Geological Society, London, Special Publication, No.49, 773-786.

[7] Ghorashi, M. (1985) ìLate Cenozoic Faulting in S.E. Iranî, G.S.I. Rep. No.54.

[8] Byrne, D.E., Sykes, L.R. and Davis, D.M. (1992) Great Thrust Earthquakes and Aseismic Slip along the Plate Boundary of the Makran Subduction Zone. Journal of Geophysical Research, 97, 449-478. https://doi.org/10.1029/91JB02165

[9] Bayer, R., Chery, J., Tatar, M., Vernant, P.H., Abbassi, M., Masson, F., Nilforoushan, F., Doerflinger, E., Regard, V. and Bellier, O. (2006) Active Deformation in Zagros-Makran Transition Zone Inferred from GPS Measurements. Geophysical Journal International, 165, 373-381. https://doi.org/10.1111/j.1365-246X.2006.02879.x

[10] Gansser, A. (1971) The Taftan volcano (SE Iran). Ecloga GEOL. HELV; CHE; VOL. 64, NUM. 0002, P. 319A 334.

[11] Jacob, K.H. and Quittmeyer, R.C. (1979) The Makran Region of Pakistan and Iran trnch-Are System with Active Plate Subduction. In: Geodynamics of Pakistan, Geological Survey of Pakistan, Quetta, 305-318.

[12] Dykstra, J.D. and Birnie, R. (1979) Segmentation of the Quaternary Subduction Zone under the Baluchistan Region of Pakistan and Iran. In: Geodynamic of Pakistan, Elite Publishers, Karachi, 319-325.

[13] Ambraseys, N.N., Douglas, J., Sarma, S.K. and Smit, P.M. (2005) Equation for the Estimation of Strong Ground Motions from Shallow Crustal Earthquakes Using Data from Europe and the Middle East: Horizontal Peak Ground Acceleration and Spectral Acceleration. Bulletin of Earthquake Engineering, 3, 1-53. https://doi.org/10.1007/s10518-005-0183-0

[14] Campbell, K.W. and Bozorgnia, Y. (2008) NGA Ground Motion Model for the Geometric Mean Horizontal Component of PGA, PGV, PGD and 5\% Damped Linear Elastic Response Spectra for Periods Ranging from 0.01 to 10s. Earthquake Spectra, 241, 139-171. https://doi.org/10.1193/1.2857546

[15] Boore, D.M. and Atkinson, G.M. (2008) Ground-Motion Prediction Equations for the Average Horizontal Component of PGA, PGV, and 5\%-Damped PSA at Spectral Periods between 0.01s and 10.0s. Earthquake Spectra, 241, 99-138. https://doi.org/10.1193/1.2830434

[16] Chiou, B.S.J. and Youngs, R.R. (2008) An NGA Model for the Average Horizontal Component of Peak Ground Motion and Response Spectra. Earthquake Spectra, 24, 173-215. https://doi.org/10.1193/1.2894832

[17] Abrahamson, N.A. and Silva, W.J. (2008) Summary of the Abrahamson \& Silva NGA Ground-Motion Relations. Earthquake Spectra, 241, 67-97. https://doi.org/10.1193/1.2924360

[18] Youngs, R.R., Chiou, S.J., Silva, W.J. and Humphrey, J.R. (1997) Strong Ground Motion Attenuation Relationships for Subduction Zone Earthquakes. Seismological Research Letters, 68, 58-73. https://doi.org/10.1785/gssrl.68.1.58

[19] Atkinson, G.M. and Boore, D.M. (2003) Empirical Ground-Motion Relations for Subduction-Zone Earthquakes and Their Application to Cascadia and Other Regions. Bulletin of the Seismological Society of America, 93, 1703-1729. https://doi.org/10.1785/0120020156 